\title{
Relationships Between River Water Quality and Landscape Factors in Haihe River Basin, China: Implications for Environmental Manage- ment
}

\author{
XU Huashan ${ }^{1}$, ZHENG Hua $^{1}$, CHEN Xiaoshu ${ }^{2}$, REN Yufen ${ }^{1}$, OUYANG Zhiyun ${ }^{1}$ \\ (1. State Key Laboratory of Urban and Regional Ecology, Research Center for Eco-Environmental Sciences, Chinese Academy of Sci- \\ ences, Beijing 100085, China; 2. Institute of Resources and Environment, Henan Polytechnic University, Jiaozuo 454003, China)
}

\begin{abstract}
River water plays a key role in human health, and in social and economic development, and is often affected by both natural factors and human activities. An in-depth understanding of the role of these factors can help in developing an effective catchment management strategy to protect precious water resources. This study analyzed river water quality, patterns of terrestrial and riparian ecosystems, intensity of agricultural activities, industrial structure, and spatial distribution of pollutant emissions in the Haihe River Basin in China for the year of 2010, identifying the variables that have the greatest impact on river water quality. The area percentage of farmland in study area, the percentage of natural vegetation cover in the 1000-m riparian zone, rural population density, industrial Gross Domestic Product (GDP) $/ \mathrm{km}^{2}$, and industrial amino nitrogen emissions were all significantly correlated with river water quality $(P<0.05)$. Farming had the largest impact on river water quality, explaining $43.0 \%$ of the water quality variance, followed by the coverage of natural vegetation in the $1000-\mathrm{m}$ riparian zone, which explained $36.2 \%$ of the water quality variance. Industrial amino nitrogen emissions intensity and rural population density explained $31.6 \%$ and $31.4 \%$ of the water quality variance, respectively, while industrial GDP/ $\mathrm{km}^{2}$ explained $26.6 \%$. Together, these five indicators explained $67.3 \%$ of the total variance in water quality. Consequently, water environmental management of the Haihe River Basin should focus on adjusting agricultural activities, conserving riparian vegetation, and reducing industrial pollutant emissions by optimizing industrial structure. The results demonstrate how human activities drive the spatial pattern changes of river water quality, and they can provide reference for developing land use guidelines and for prioritizing management practices to maintain stream water quality in a large river basin.
\end{abstract}

Keywords: land use; watershed management; river water quality; gradient analysis

Citation: Xu Huashan, Zheng Hua, Chen Xiaoshu, Ren Yufen, Ouyang Zhiyun, 2016. Relationships between river water quality and landscape factors in Haihe River Basin, China: implications for environmental management. Chinese Geographical Science, 26(2): 197-207. doi: 10.1007/s11769-016-0799-9

\section{Introduction}

River water quality plays a key role in human health and in social and economic development. Likewise, human activities and social and economic factors affect patterns of land use and land cover (Lee et al., 2009; Wan et al., 2014), and alter the water cycle and river water quality.
For example, research has revealed that the nitrate-N load of river water is relatively complex and dependent on, among other things, the proportion and type of agriculture, such as grassland, and whether there are wastewater treatment plants (WWTPs) in a river basin (Ahearn et al., 2005). Rapid urbanization and industrialization cause heterogeneity in land use, and land use in

Received date: 2015-06-19; accepted date: 2015-10-15

Foundation item: Under the auspices of National Natural Science Foundation of China (No. 41371538), Independent Project of State Key Laboratory of Urban and Regional Ecology, Research Center for Eco-Environmental Sciences, Chinese Academy of Sciences (No. SKLURE2008-1-02)

Corresponding author: ZHENG Hua. E-mail: zhenghua@rcees.ac.cn

(C) Science Press, Northeast Institute of Geography and Agroecology, CAS and Springer-Verlag Berlin Heidelberg 2016 
turn restricts the development of social and economic activities. Thus, land use patterns and social and economic activities interact with each other, and jointly act on a river's ecological systems to significantly change water quality in a river basin (Uriarte et al., 2011; Liu et al., 2013; Teixeira et al., 2014). It is necessary, therefore, to take both land use type and various social and economic characteristics into account to more accurately reflect their impacts on water quality (Wang et al., 2012).

The concentrations of the pollutants in water have been shown to have a significant positive correlation with the urban land use area (Zhao et al., 2012). Both farmland and urban land use are important sources of total nitrogen (TN) and total phosphorus (TP) in water (Wan et al., 2014); together these land use types can explain $25 \%-75 \%$ of water quality variance in a regression model (Mehaffey et al., 2005), and the nitrate-N content in water has a close relationship with the area proportions of farmland and grassland in river basin (Ahearn et al., 2005). Wang et al. (2001) found that the areas of farmland and grassland have a great influence on river water quality, and increases in these areas can significantly improve river water quality (Huang et al., 2013).

Complete riparian zones can effectively protect and improve river water quality (Collins et al., 2013; Randhir and Ekness, 2013); 200-m riparian zones in agricultural and urban areas can effectively reduce non-point source load (Tran et al., 2010), and forest riparian zones can significantly protect and improve river water quality (Fernandes et al., 2014). Conversely, reduction in vegetation density in riparian zones can result in increased amounts of fecal bacteria in surface water (Ragosta et al., 2010). Ding et al. (2013) found that at the 100-500 $\mathrm{m}$ scale, the grassland in riparian zones can significantly decrease the conductivity and total dissolved solids concentration in water; at the $25-500 \mathrm{~m}$ scale, the farmland and residential land have significantly negative correlation with the river water quality parameters. The vegetation in a riparian zone and the forest structure in a riparian zone influence both conductivity and amino nitrogen concentration in water, and the forest structure in a riparian zone influences TP and dissolved phosphorus (de Souza et al., 2013).

In the Haihe River Basin, Sun et al. (2013) stated that agricultural and residential land use and stockbreeding are the main factors causing river water quality degradation in the upstream mountainous areas, and that domestic wastewater, animal and human excreta and solid waste emissions significantly influence the river water quality in the downstream plain areas. Sun et al. (2013) also found that the upstream agricultural areas have insignificant correlation with the total nitrogen content of river water quality. They inferred that the industrial wastewater emissions might be a main factor leading to water pollution in the downstream plain areas.

One of the great challenges faced by river basin managers is to know how to identify the main factors influencing river water quality and their relative contributions from among the multiple complex factors that do so. Due to differences in natural, social, and economic characteristics, the measures needed to control pollution and improve water quality are not the same for all river basins. Therefore, research efforts on water resource management strategies for specific river basins are urgently needed to provide effective guidance for managing regional river water quality.

Water pollution is severe in the Haihe River Basin. Intensive agricultural activities (Zheng et al., 2015), rapidly developing industry and urbanization, and dense population all greatly change the terrestrial ecosystem patterns in the river basin, increase the output of industrial point source pollution and agricultural non-point source pollution, and significantly impact river water quality. According to the Haihe River Water Conservancy Commission's Water Resources Bulletin (2010) (http://www.hwcc.gov.cn/pub/hwcc/static/szygb/gongba o2010/index.htm), 'seriously polluted' water, 'moderately polluted' water, and 'clean' water accounted for $48.2 \%, 14.6 \%$, and $37.2 \%$, respectively, in an evaluated stretch of river in the Haihe River Basin. It is essential to understand the primary factors responsible for river pollution so that effective, context-specific river basin environmental management strategies can be developed.

This paper describes a case study of the relationships between river water quality and landscape factors in the Haihe River Basin. Data for a variety of river basin features were collected and analyzed, and the influence of these factors on river water quality was quantitatively evaluated to provide basic information for developing guidelines on river basin water resource management. 


\section{Materials and Methods}

\subsection{Study area}

The Haihe River Basin, located in the northeastern China, is an important heavy industry and high-tech industrial region, but where grain production also is significant. It covers all or parts of 355 counties and districts, including the cities of Beijing and Tianjin, most of Hebei Province, the eastern and northern parts of Shanxi Province, the northern parts of Shandong and Henan provinces, and small parts of the Inner Mongolia Autonomous Region and Liaoning Province. The basin comprises approximately $320000 \mathrm{~km}^{2}$, including mountains of $186900 \mathrm{~km}^{2}$ (58.4\% of the land area), and plains of $131400 \mathrm{~km}^{2}(41.3 \%)$. In 2010, the total population in the Haihe Basin was $1.40 \times 10^{8}$, and cultivated land accounted for $1.29 \times 10^{7}$ ha (or $45.0 \%$ ) of the land area. There are numerous river systems in the Haihe River Basin, the major ones being the Haihe, Luanhe, and Tuhai-Majia river. According to the Water Resource Partition Map of China (General Institute of Water Resources and Hydropower Planning and Design, Ministry of Water Resources of China), the Haihe River Basin is divided into 15 third grade Water Resource Zones based on sub-basin boundaries (Fig. 1).

\subsection{Data sources}

River water quality is affected by land use patterns, industrial point source discharge load, agricultural nonpoint source load, and other socioeconomic factors (Sun et al., 2013). Based on the framework and the characteristics of the social economy in the Haihe River Basin, river water characteristics and the factors influencing them were analyzed, including terrestrial ecosystem patterns; natural vegetation coverage in different riparian zones; proportions of the economy in agriculture, services, and industry; industrial and domestic wastewater emissions; and agricultural production activities (Table 1).

Land use data and natural vegetation coverage data in 2010 originated from Thematic Mapper (TM) images (30 $\mathrm{m} \times 30 \mathrm{~m}$ resolution), which were obtained from the Institute of Remote Sensing and Digital Earth, Chinese Academy of Sciences. Land use was classified into six types: forestland, grassland, wetland, farmland, artificial surface and 'others'. The land use type and natural vegetation coverage $(30 \mathrm{~m} \times 30 \mathrm{~m}$ resolution) in 2010 was analyzed in $500-\mathrm{m}, 1000-\mathrm{m}$ and $2000-\mathrm{m}$ riparian zones.

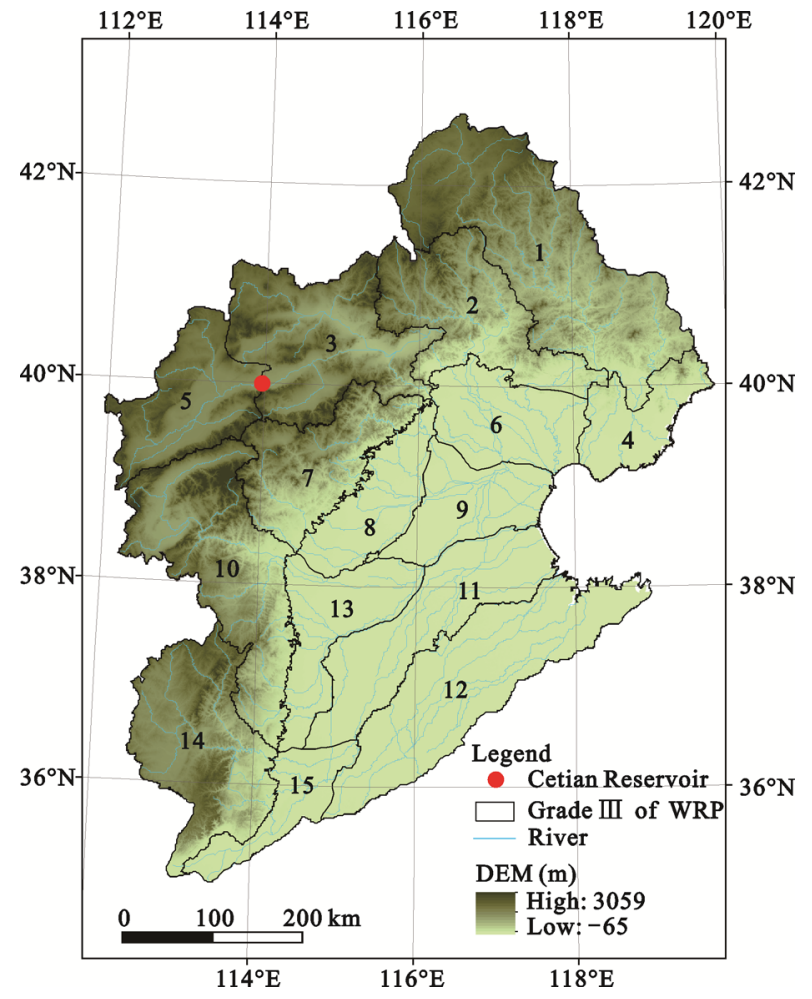

Fig. 1 Schematic map of third grade Water Resource Zones of Haihe River Basin, China. 1: Luanhe River mountainous zone; 2: Beisanhe River mountainous zone; 3: zone from the Cetian Reservoir to Sanjiadian along the Yongding River; 4: zone of the Luanhe Plain and various coastal rivers in eastern Hebei; 5: zone of upstream of the Cetian Reservoir along the Yongding River; 6: Beisihe River downstream plain zone; 7: Daqing River mountainous zone; 8: Daqing River Dianxi plain zone; 9: Daqing River Diandong plain zone; 10: Ziya River mountainous zone; 11: Heilonggang and Yundong plain zone; 12: Tuhai-Majia River plain zone; 13: Ziya River plain zone; 14: Zhangwei River mountainous zone; 15: Zhangwei River plain zone. WRP: Water Resource Partition

The data defining the intensity of agricultural activities, industrial structure, and intensity of industrial and domestic wastewater emissions (all at county scale in 2010) were also collected from the Chinese Academy of Agricultural Sciences and from the Ministry of Environmental Protection (Table 1).

In the study, multiple indicators of river water quality were not utilized directly to present the spatial characteristics of river water quality due to the lack of direct monitoring data. Instead, water quality grades (Table 2) were used to present the relative differences of river water quality among the 15 third grade Water Resource Zones, data for which were provided by the Haihe River Water Conservancy Commission, Ministry of Water 
Resources, China (http://www.hwcc.gov.cn/pub/hwcc/ static/szygb/gongbao2010/index.htm). The river water quality grades were classified according to the Environmental Quality Standards for Surface Water in China (GB 3838-2002) (http://www.es.org.cn/download/35-1. pdf). In the classification system, river water quality is divided into six grades (i.e., grades I, II, III, IV, V and 'worse than Grade $V$ ') based on the lowest of five monitoring indicators (Table 2).

\subsection{Data analysis}

Data were analyzed at the level of 15 third grade Water Resource Zones by aggregating all county-level data into third grade Water Resource Zones using a weighted-average calculation. First, all the data were subjected to $\log$ transformation $[\lg (N+1)]$, as they were not normally distributed. Gradient analysis methods (Jan and Petr, 2003) introduced from the plant ecology study field, such as redundancy analysis (RDA), correspondence analysis, and canonical correspondence analysisare used to analyze the influence of watershed ecosystem patterns on water quality (Zhao et al., 2011; Ortolani, 2014). Redundancy analysis was conducted on the terrestrial ecosystem data categories with water quality in 2010 as the dependent variable. Data analyzed as independent variables using this technique included the riparian zone $(500 \mathrm{~m}, 1000 \mathrm{~m}$ and $2000 \mathrm{~m})$ ecosystem categories and natural vegetation cover, the intensity of agricultural activities (as measured by gross agricultural, crop, and livestock output; rural per capita income; agricultural population density; and pesticide and fertilizer application density); proportions of the economy in agriculture, services, and industry; and industrial and domestic wastewater emissions.

Table 1 Data sources and explanations

\begin{tabular}{|c|c|c|c|}
\hline Data type & Data item & Data scale & Data source \\
\hline Water quality & $\begin{array}{l}\text { Proportion of water quality in the monitored river reach having } \\
\text { Grades I, II and III, combined; grades IV and V, combined; } \\
\text { and worse than Grade V }\end{array}$ & $\begin{array}{l}\text { Haihe River } \\
\text { Basin }\end{array}$ & $\begin{array}{l}\text { Water Quality Distribution Map in } 2010 \text { on website of Haihe } \\
\text { River Water Conservancy Commission, Ministry of Water } \\
\text { Resources, China (http://www.hwcc.gov.cn/pub/hwcc/static/ } \\
\text { szygb/gongbao2010/index.htm) }\end{array}$ \\
\hline Land use & $\begin{array}{l}\text { Proportions of land in use categories, including forest, } \\
\text { grassland, wetland, farmland, artificial surface, and others }\end{array}$ & $\begin{array}{l}\text { Haihe River } \\
\text { Basin }\end{array}$ & $\begin{array}{l}\text { Institute of Remote Sensing and Digital Earth, Chinese } \\
\text { Academy of Sciences }\end{array}$ \\
\hline Riparian zone & $\begin{array}{l}\text { Land use type and natural vegetation coverage in } 500 \mathrm{~m} \text {, } \\
1000 \mathrm{~m} \text { and } 2000 \mathrm{~m} \text { riparian zones }\end{array}$ & $\begin{array}{l}\text { Haihe River } \\
\text { Basin }\end{array}$ & $\begin{array}{l}\text { Institute of Remote Sensing and Digital Earth, Chinese } \\
\text { Academy of Sciences }\end{array}$ \\
\hline $\begin{array}{l}\text { Natural vegetation } \\
\text { coverage }\end{array}$ & $\begin{array}{l}\text { Proportions of forest, grassland and wetland area in } 500-\mathrm{m} \text {, } \\
1000-\mathrm{m}, 2000-\mathrm{m} \text { riparian zones }\end{array}$ & $\begin{array}{l}\text { Haihe River } \\
\text { Basin }\end{array}$ & $\begin{array}{l}\text { Institute of Remote Sensing and Digital Earth, Chinese } \\
\text { Academy of Sciences }\end{array}$ \\
\hline $\begin{array}{l}\text { Intensity of } \\
\text { agricultural } \\
\text { activities }\end{array}$ & $\begin{array}{l}\text { Gross agricultural output }\left(10000 \text { yuan }(\mathrm{RMB}) / \mathrm{km}^{2}\right) \text {, gross } \\
\text { crop output }\left(10000 \text { yuan }(\mathrm{RMB}) / \mathrm{km}^{2}\right) \text {, gross livestock output } \\
\left(10000 \text { yuan }(\mathrm{RMB}) / \mathrm{km}^{2}\right) \text {, rural per capita net income, } \\
\text { agricultural population density, pesticide application intensity, } \\
\text { and fertilizer application intensity }\end{array}$ & County & Chinese Academy of Agricultural Sciences \\
\hline $\begin{array}{l}\text { Industrial } \\
\text { structure }\end{array}$ & $\begin{array}{l}\text { Agricultural GDP } / \mathrm{km}^{2} \text {, industrial GDP } / \mathrm{km}^{2} \text {, and services } \\
\mathrm{GDP} / \mathrm{km}^{2}\end{array}$ & County & Ministry of Environmental Protection, China \\
\hline $\begin{array}{l}\text { Industrial and } \\
\text { domestic } \\
\text { wastewater } \\
\text { emissions } \\
\text { intensity }\end{array}$ & $\begin{array}{l}\text { Industrial wastewater emission intensity, industrial wastewater } \\
\text { COD emission intensity, industrial wastewater amino nitrogen } \\
\text { emission intensity, domestic wastewater emission intensity, } \\
\text { domestic wastewater COD emission intensity, domestic } \\
\text { wastewater amino nitrogen emission intensity }\end{array}$ & County & Ministry of Environmental Protection, China \\
\hline
\end{tabular}

Note: GDP is Gross Domestic Product; COD is Chemical Oxygen Demand

Table 2 Threshold of surface water quality indicators for grades I to $\mathrm{V}$

\begin{tabular}{|c|c|c|c|c|c|}
\hline \multirow{2}{*}{ Indicators $(\mathrm{mg} / \mathrm{L})$} & \multicolumn{5}{|c|}{ Grade } \\
\hline & I & II & III & IV & $\mathrm{V}$ \\
\hline Chemical Oxygen Demand (COD) & 15 & 15 & 20 & 30 & 40 \\
\hline Five-day Biochemical Oxygen Demand $\left(\mathrm{BOD}_{5}\right)$ & 3 & 3 & 4 & 6 & 10 \\
\hline Ammonia Nitrogen $\left(\mathrm{NH}_{3}-\mathrm{N}\right)$ & 0.15 & 0.50 & 1.00 & 1.50 & 2.00 \\
\hline Total Phosphorus (TP) & 0.02 & 0.10 & 0.20 & 0.30 & 0.40 \\
\hline Total nitrogen $(\mathrm{TN})$ & 0.2 & 0.5 & 1.0 & 1.5 & 2.0 \\
\hline
\end{tabular}


The CANOCO RDA software (v. 4.5) identified the five variables that had the largest influence on river water quality $(P<0.05)$. These variables were the area percentage of farmland in study area, the percentage of natural vegetation cover in the $1000-\mathrm{m}$ riparian zone, rural population density, industrial $\mathrm{GDP} / \mathrm{km}^{2}$, and industrial amino nitrogen emissions. The RDA analysis was then repeated using the selected five indicators as explanatory variables in the CANOCO software to calculate the amount of river water quality variance explained by the different variables.

\section{Results}

\subsection{Spatial pattern of river water quality}

The mountainous areas in the upper Haihe River Basin have good river water quality, with more than $60 \%$ of the water in Grades I, II, and III totally (Fig. 2a). In the upstream area, only the Cetian Reservoir on the Yongding River has poor water quality. The downstream plains areas universally have poor river water quality, with more than $60 \%$ of the river water having water quality worse than Grade V. In the downstream plains area, only the Luanhe Plain and various coastal rivers in the eastern Hebei Province have good river water quality.

\subsection{Characteristics of land use and socioeconomic factors}

\subsubsection{Land use}

Farmland has the largest area in terrestrial ecosystems of the Haihe River Basin in 2010, accounting for $45 \%$ of the total area, followed by forestland, which accounted for $29 \%$ (Fig. 2b). Of ecosystems in the 1000-m riparian zone, farmland, artificial surfaces, and forestland accounted for $54 \%, 13 \%$, and $17 \%$ of land area, respectively (Fig. 2c). The ecosystem and natural vegetation coverage proportion of the $1000-\mathrm{m}$ riparian zone present obvious spatial characteristic (Figs. $2 \mathrm{~b}$ and $2 \mathrm{c}$ ). In northwest mountainous area, land use mainly includesforest, grassland, but southwest plains was farmland.

\subsubsection{Socioeconomic factors}

The spatial distributions of GDP/ $\mathrm{km}^{2}$ for agriculture, industry, and services follow approximately the same as that of river water quality in the Haihe River Basin (Figs. 3a, 3b and 3c). The spatial distribution of GDP is relatively low in the mountainous upstream region but relatively high in the plains areas of the downstream region. The distribution of agricultural activities is consistent with the spatial pattern of GDP for agriculture, industry, and services. Rural population densities are all higher in the downstream plains areas than those in the upstream mountainous areas.

Compared with the upstream mountainous areas, industrial amino nitrogen emissions in the downstream plains areas are also greater. However, it should be noted that the above mentioned indicators are all at higher levels in the Zhangwei River mountainous area than in other upstream mountainous areas, and are even higher than some of the downstream plains areas (Figs. $3 a, 3 b$ and $3 c)$.
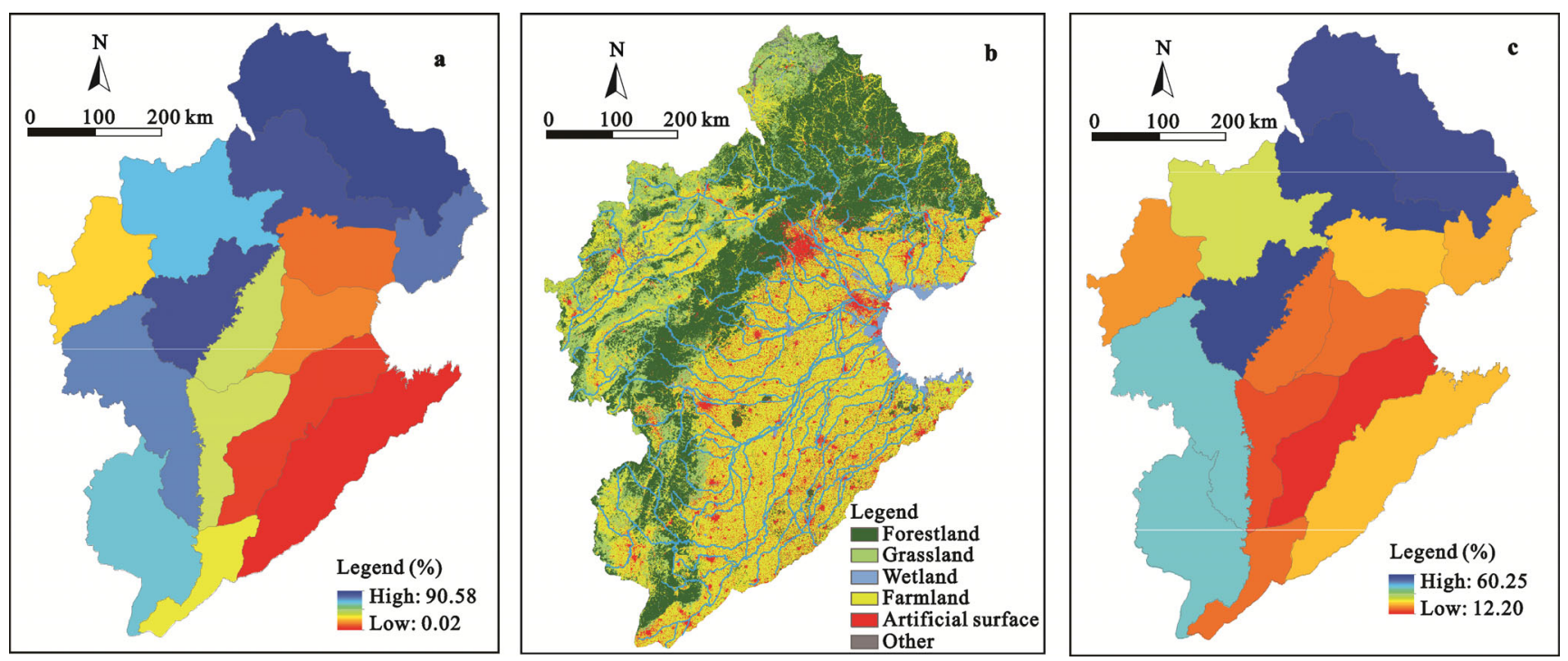

Fig. 2 Proportion of water quality with grades I, II and III in 15 WRP (a), terrestrial ecosystems in 2010 (b), and proportion of natural vegetation coverage in 1000-m riparian zone (c) in Haihe River Basin 

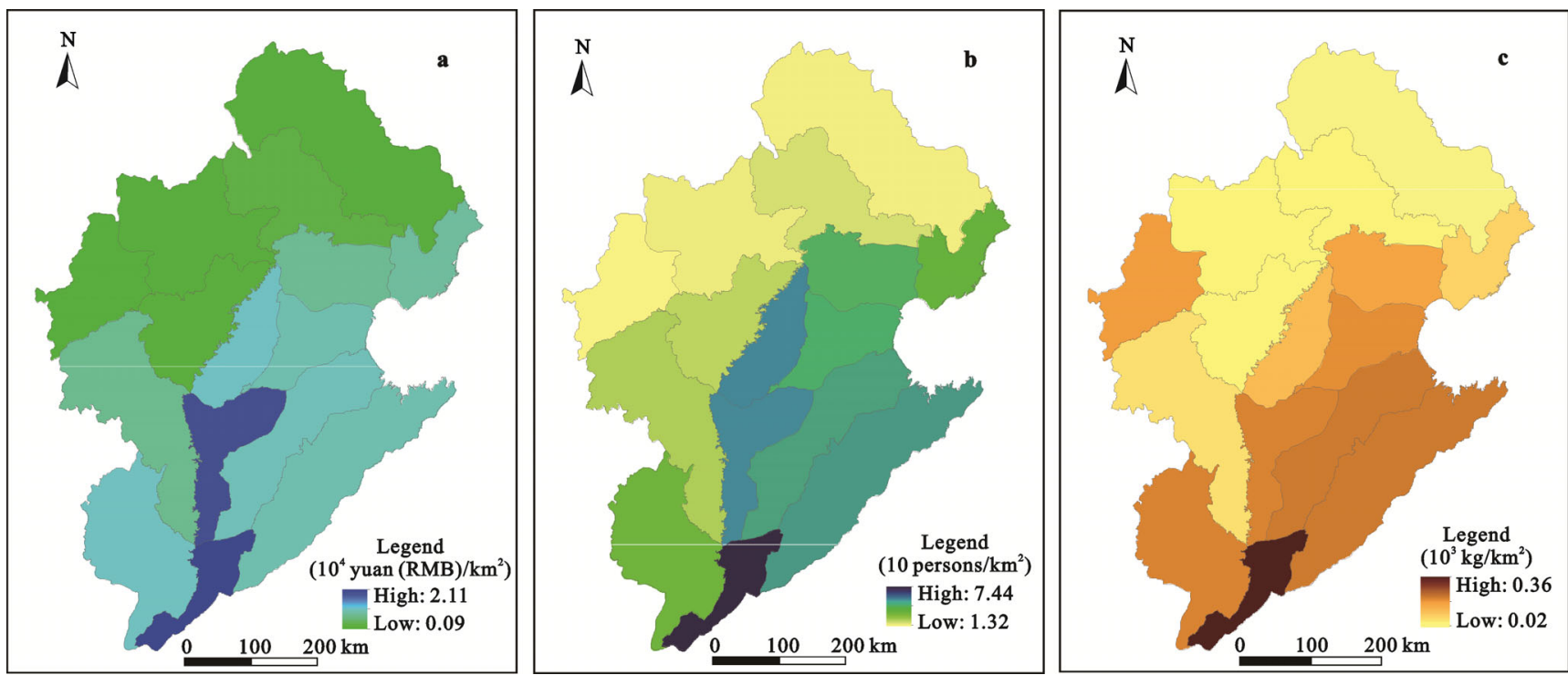

Fig. 3 Spatial patterns of industrial Gross Domestic Product (GDP) density (a), agricultural population density (b), and industrial amino nitrogen (IWAN) emission intensity (c) in Haihe River Basin

\subsection{Relationships between river water quality,} land use, and socioeconomic development

Redundancy analysis indicated that collectively, the independent variables explain $67.2 \%$ of the total river water quality variance (Fig. 4). The horizontal axis (Axis 1) explains $46.2 \%$ of the variance for river water quality categorized as Grades I, II, and III (combined) in the river basin. Of the explanatory variables, natural vegetation cover in the 1000-m riparian zone had the strongest positive correlation with the proportion of river water quality in Grades I, II, and III (combined). In other words, the greater is the coverage of natural vegetation in the 1000 -m riparian zone, the better is the water quality. Natural vegetation cover in the $1000-\mathrm{m}$ riparian zone can explain up to $36.2 \%$ of the variance in river water quality $(P<0.05)$. Industrial amino nitrogen emissions, farmland area, agricultural population density, and industrial $\mathrm{GDP} / \mathrm{km}^{2}$ all had strongly negative correlations with the proportion of river water quality in Grades I, II, and III (detailed results of correlation analyses are given in the annexed table).

The vertical axis (Axis 2) explains 19.1\% of the variance in the proportion of river water having quality worse than Grade V in the river basin. Of the explanatory variables, industrial amino nitrogen emissions, area percentage of farmland in study area, agricultural population density, and industrial GDP/ $\mathrm{km}^{2}$ were significantly positively correlated with the proportion of river water in the river basin having quality worse than Grade
V. The degrees of correlation rank as follows: industrial amino nitrogen emissions intensity $>$ area percentage of

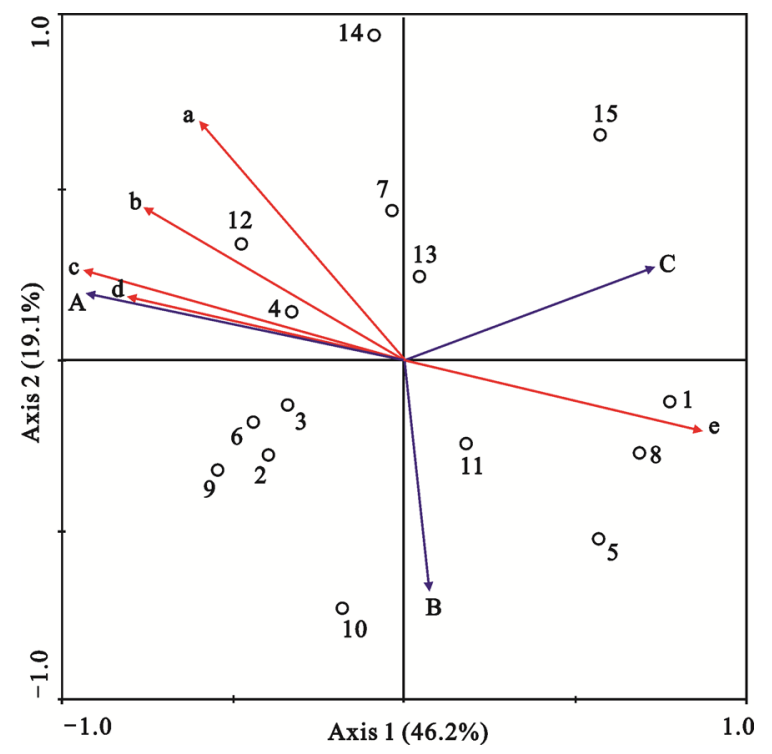

Fig. 4 Ordination diagram for redundancy analysis of explanatory variables (red lines) and river water quality variables (blue lines). Arrow lengths represent the loading of each variable on the two canonical axes. Percentages are the percent variance in river water quality explained by each axis. A: proportion of river water with quality worse than grade $\mathrm{V}$; B: proportion of river water with quality in grades IV and $\mathrm{V}$, combined; $\mathrm{C}$ : proportion of river water with quality in grades I, II, III, combined; a: industrial GDP $/ \mathrm{km}^{2}$; b: agricultural population density; c: area percentage of farmland in study area; d: industrial amino nitrogen emissions; e: percent of natural vegetation cover in $1000 \mathrm{~m}$ riparian zone. The numbers in the figure represent the 15 Water Resource Partition (WRP) 
farmland in study area $>$ agricultural population density $>$ industrial GDP $/ \mathrm{km}^{2}$. The amount of variance explained by these variables individually is $43.0 \%$ by farmland, $31.6 \%$ by industrial amino nitrogen emissions, $31.4 \%$ by rural population density, and $26.6 \%$ by industrial GDP $/ \mathrm{km}^{2}(P<0.05)$.

\section{Discussion}

Water resources in the Haihe River Basin are among the most polluted in China (Zheng et al., 2015). Among the 15 third grade Water Resource Zones, water quality was generally better in the mountainous zones than in the plain zones, which is consistent with the research results obtained by Sun et al. (2013). However, the present study shows that there are several zones with poor river water quality in the upstream areas of the river basin. For example, the upstream of the Cetian Reservoir along the Yongding River (the red dot in the Fig. 1) has water quality dominated by categories in Grade IV, Grade V and worse than Grade V, which collectively account for $74.66 \%$ of all water. Likewise, there are zones with good river water quality in downstream plain areas. For example, the zone of the Luanhe Plain and various coastal rivers in the eastern Hebei have $75.31 \%$ of water with river water quality in Grades I, II and III. The Zhangwei River mountainous zone in the upstream part of the Haihe River Basin has a number of indicators (i.e., industry GDP density, industrial wastewater emission per unit area, industrial COD emission, industrial amino nitrogen emission, domestic wastewater emission per unit area, domestic COD emission, and domestic amino nitrogen emission) that are higher than those in other upstream mountainous areas, and even higher than those in some downstream plain areas. The Yuecheng Reservoir located in this area assumes the task of urban, industrial and agricultural water supply to Anyang, Handan, and other cities. As one of the first recognized important drinking water source locations in China, this area shall be closely examined and monitored by the river basin administrative agency.

Understanding the relationships between river water quality and landscape factors is the foundation of effective water pollution control planning. The results of the redundancy analysis in this project show that river water quality is significantly associated with patterns of economic development, agricultural development, and land use in the Haihe River Basin. The main factors causing river water quality degradation include the area percentage of farmland in study area, the proportion of riparian zone covered by natural vegetation, industrial amino nitrogen emissions, agricultural population density, and industrial GDP/ $/ \mathrm{km}^{2}$ (Fig. 4). Sun et al. (2013) made similar conclusions in a study on the relationship between land use and total nitrogen in surface water in the Haihe River Basin. They inferred that industrial wastewater emissions might be a main factor leading to water pollution in the downstream plain areas, a supposition corroborated in the present study. On the scale of the whole Haihe River Basin, the farmland ratio is a very important factor causing river water quality degradation, especially in the downstream plain areas. However, Sun et al. (2013) found that the agricultural areas in the upstream zones have insignificant correlation with the total nitrogen content of river water.

Accounting for more than $10 \%$ of the China's total grain yield, the Haihe River Basin is one of the top three grain producing areas in the country. In addition, the Haihe River Basin is a 'vegetable basket' production base for mega cities such as Beijing and Tianjin. In the present study, the area percentage of farmland in study area had the highest contribution for river water quality variance, while agricultural population density also had a significant contribution, especially in the downstream plain (Fig. 4). These results can be seen in the Water Resource Zones such as the Heilonggang and Yundong Plain and the Tuhai-Majia River Plain, where agricultural development significantly drives the water shortages and water pollution in the Haihe River Basin. Sun et al. (2013) came to similar conclusions in their study on the relationship between land use and total nitrogen levels in river water in the Haihe River Basin. At the scale of the entire Haihe River Basin, the area percentage of farmland in study area is an important factor linked to river water quality degradation. Furthermore, the agricultural chemical fertilizer application is still increasing. Chemical fertilizer nitrogen input increased by $51.7 \%$ between 1990 and 2010 and by $37.2 \%$ from 2000 to 2010 , concomitant with increasing crop yields (Zheng et al., 2015).

Riparian zones help shade and partially protect a stream from the impact of adjacent land uses. Intact riparian zones can effectively protect and improve river water quality (Collins et al., 2013; Randhir and Ekness, 
2013). Reduction in vegetation density in riparian zones can increase the amount of amino nitrogen, total phosphorus and dissolved phosphorus in river water (Ragosta et al., 2010). In this study, the extent of natural vegetation cover in the 1000-m riparian zone had a significant positive influence on river water quality, explaining $36.2 \%$ of the variance of river water quality in the Haihe River Basin (Fig. 4). The results suggest that the destruction of natural vegetation in a riparian zone by urban expansion and agricultural developmentin the Haihe River Basin caused deterioration in river water quality.

Other factors causing river water quality degradation are economic development (indicated by GDP) and pollutant emissions due to rapid industrialization and urbanization, especially point source pollution caused by amino nitrogen emissions in the Haihe River Basin (Fig. 4). The Haihe River Basin is an important heavy industry and high-tech industrial base, and rapid economic growth has increased the output of industrial point source pollution. Sun et al. (2013) proposed that industrial wastewater emissions might be the main factor leading to water pollution in the downstream plains region. Therefore, it is urgent to balance economic development and water environmental protection in regions experiencing extreme water shortages in China.

By revealing the spatial characteristics of river water quality and the factors influencing water quality, this study suggests that management strategies tailored to different areas may help protect and improve river water quality in the Haihe River Basin.

(1) Strengthened legislation for riparian zones is needed to increase the natural vegetation cover in $1000-\mathrm{m}$ riparian zones; to spur implementation of projects that restore farmland to forestland, grassland, or wetlands; and to enhance the construction of riparian zones, so that these zones truly become an effective barrier protecting and improving water quality in the river basin.

(2) In regions that have high levels of agricultural activity or high rural population density, river water quality could be protected by reducing the intensity of agricultural activities in the river basin, or by decreasing the agricultural non-point source pollution load through measures such as reducing farmland area or decreasing the use of pesticides, herbicides, and petrochemical fertilizers in the river basin.
(3) In regions that have heavy point source pollution loads, additional wastewater treatment plants could be constructed to increase wastewater treatment efficiency and effectiveness, reducing the influence of point source pollution on river water quality. The mix of industries in the region could be adjusted by restricting development of those industries having high water consumption or pollution emissions, and by actively implementing clean production technologies, to promote sustainable economic development in the river basin.

(4) Establishing river basin water resource management systems based on combined watershed zoning and area zoning management, adapted to the features of the Haihe River Basin, could enhance supervision and management of Water Resource Zones. This is especially important for protection of drinking water source locations such as the Guangting Reservoir in Beijing which was the second largest reservoir in Beijing, but was closed in 1997 due to heavy concentrations of wastewater discharge, fertilizers, and pesticides (Zheng et al., 2013).

\section{Conclusions}

This study analyzed the influence of ecosystem patterns, industrial structures, and human activities, including industrial and agricultural production, on river water quality in the Haihe River Basin of the northeastern China. This watershed is characterized by complex ecosystem patterns and intense agricultural activities, and is experiencing rapid industrialization and urbanization. These factors exert differing degrees of influence on the watershed's river water quality. The areal extent of farmland has the largest influence, explaining $43.0 \%$ of the variance in river water quality, followed by the extent of natural vegetation coverage in the 1000-m riparian zone, which explains $36.2 \%$ of the river water quality variance. Other influential factors include industrial amino nitrogen emissions (explaining $31.6 \%$ of river water quality variance), rural population density (31.4\%), and industrial GDP $/ \mathrm{km}^{2}(26.6 \%)$. The total variance in river water quality explained by these five factors is $67.3 \%$. Thus, the main factors influencing river water quality in the Haihe River Basin are agricultural non-point source pollution, natural vegetation destruction, and industrial point source pollution. This conclusion highlights the need to take into consideration 
the targeted pollution sources and the conservation of riparian vegetation when developing management strategies for the protection of vulnerable water resources.

\section{References}

Ahearn D S, Sheibley R W, Dahlgren R A et al., 2005. Land use and land cover influence on water quality in the last free-flowing river draining the western Sierra Nevada, California. Journal of Hydrology, 313(3): 234-247. doi: 10.1016/j. jhydrol.2005.02.038

Collins K E, Doscher C, Rennie H G et al., 2013. The effectiveness of riparian 'restoration' on water quality: a case study of lowland streams in Canterbury, New Zealand. Restoration Ecology, 21(1): 40-48. doi: 10.1111/j.1526-100X.2011.00859.x

de Souza A L T, Fonseca D G, Liborio R A et al., 2013. Influence of riparian vegetation and forest structure on the water quality of rural low-order streams in SE Brazil. Forest Ecology and Management, 298: 12-18. doi: 10.1016/j.foreco.2013.02.022

Ding S, Zhang Y, Liu B et al., 2013. Effects of riparian land use on water quality and fish communities in the headwater stream of the Taizi River in China. Frontiers of Environmental Science \& Engineering, 7(5): 699-708. doi: 10.1007/s11783013-0528-x

Fernandes J d F, de Souza A L T, Tanaka M O, 2014. Can the structure of a riparian forest remnant influence stream water quality? A tropical case study. Hydrobiologia, 724(1): 175185. doi: 10.1007/s10750-013-1732-1

Huang J, Zhan J, Yan H, et al., 2013. Evaluation of the impacts of land use on water quality: a case study in the Chaohu lake basin. Scientific World Journal, (2013): 1-7. doi: 10. 1155/2013/ 329187

Jan L, Petr S, 2003. Multivariate Analysis of Ecological Data Using CANOCO. Cambridge: Cambridge University Press, 25-42.

Lee S W, Hwang S J, Lee S B et al., 2009. Landscape ecological approach to the relationships of land use patterns in watersheds to water quality characteristics. Landscape and Urban Planning, 92(2): 80-89. doi: 10.1016/j.landurbplan.2009.02. 008

Liu Z, Wang Y, Li Z et al., 2013. Impervious surface impact on water quality in the process of rapid urbanization in henzhen, China. Environmental Earth Sciences, 68(8): 2365-2373. doi: 10.1007/s12665-012-1918-2

Mehaffey M, Nash M, Wade T et al., 2005. Linking land cover and water quality in New York City's water supply watersheds. Environmental Monitoring and Assessment, 107(1-3): 29-44. doi: 10.1007/s10661-005-2018-5

Ortolani V, 2014. Land use and its effects on water quality using the BASINS model. Environmental Earth Sciences, 71(5): 2059-2063. doi: 10.1007/s12665-013-2607-5
Ragosta G, Evensen C, Atwill E et al., 2010. Causal connections between water quality and land use in a rural tropical island watershed. EcoHealth, 7(1): 105-113. doi: 10.1007/s10393010-0299-9

Randhir T O, Ekness P, 2013. Water quality change and habitat potential in riparian ecosystems. Ecohydrology \& Hydrobiology, 13(3): 192-200. doi: 10.1016/j.ecohyd.2013.09.001

Sun R, Wang Z, Chen L et al., 2013. Assessment of surface water quality at large watershed scale: land-use, anthropogenic, and administrative impacts. Journal of the American Water Resources Association, 49(4): 741-752. doi: 10.1111/jawr.12033

Teixeira Z, Teixeira H, Marques J C, 2014. Systematic processes of land use/land cover change to identify relevant driving forces: Implications on water quality. Science of the Total Environment, 470: 1320-1335. doi: 10.1016/j.scitotenv.2013.10. 098

Tran C P, Bode R W, Smith A J et al., 2010. Land-use proximity as a basis for assessing stream water quality in New York State (USA). Ecological Indicators, 10(3): 727-733. doi: 10.1016/j. ecolind.2009.12.002

Uriarte M, Yackulic C B, Lim Y et al., 2011. Influence of land use on water quality in a tropical landscape: a multi-scale analysis. Landscape Ecology, 26(8): 1151-1164. doi: 10.1007/s10980011-9642-y

Wan R, Cai S, Li H et al., 2014. Inferring land use and land cover impact on stream water quality using a Bayesian hierarchical modeling approach in the Xitiaoxi river watershed, China. Journal of Environmental Management, 133: 1-11. doi: 10. 1016/j.jenvman.2013.11.035

Wang Jiao, Ma Keming, Zhang Yuxin et al., 2012. Impacts of land use and socioeconomic activity on river water quality. Acta Scientiae Circumstantiae, 32(1): 57-65. (in Chinese)

Wang L, Lyons J, Kanehl P et al., 2001. Impacts of urbanization on stream habitat and fish across multiple spatial scales. Environmental Management, 28(2): 255-266. doi: 10.1007/s0026 702409

Zhao Jun, Yang Kai, Tai Jun et al., 2011. Review of the relationship between regional landscape pattern and surface water quality. Acta Ecologica Sinica, 31(11): 3180-3189. (in Chinese)

Zhao Peng, Xia Beicheng, Qin Jianqiao et al., 2012. Multivariate correlation analysis between landscape pattern and water quality. Acta Ecologica Sinica, 32(8): 2331-2341. (in Chinese)

Zheng H, Robinson B E, Liang Y C et al., 2013. Benefits, costs, and livelihood implications of a regional payment for ecosystem service program. Proceedings of the National Academy of Sciences, 110(41): 16681-16686. doi: 10.1073/pnas.1312324 110

Zheng M, Zheng $\mathrm{H}$, Wu Y et al., 2015. Changes in nitrogen budget and potential risk to the environment over 20 years (1990-2010) in the agroecosystems of the Haihe Basin, China. Journal of Environmental Sciences, 28: 195-202. doi: 10. 1016/j.jes.2014.05.053 
Annexed table Correlation analysis between water quality and influencing factors

\begin{tabular}{|c|c|c|c|}
\hline \multirow{2}{*}{ Influencing factors } & \multicolumn{3}{|c|}{ Water quality } \\
\hline & Grades I, II and III (\%) & Grades IV and V (\%) & Worse than Grade V (\%) \\
\hline Forest (\%) & $0.838^{* *}$ & 0.041 & $-0.882^{* *}$ \\
\hline Grassland (\%) & $0.523^{*}$ & 0.328 & $-0.668^{* *}$ \\
\hline Wetland (\%) & -0.378 & -0.182 & 0.461 \\
\hline Farmland (\%) & $-0.824^{* *}$ & -0.139 & $0.906^{* *}$ \\
\hline Artificial surface area (\%) & $-0.732^{* *}$ & -0.210 & $0.838^{* *}$ \\
\hline Other land use (\%) & -0.053 & $0.605^{*}$ & -0.180 \\
\hline $\begin{array}{l}\text { Proportion between forest area }\left(\mathrm{km}^{2}\right) \text { and total area }\left(\mathrm{km}^{2}\right) \\
\text { in } 500 \mathrm{~m} \text { riparian zones }(\%)\end{array}$ & 0.080 & -0.161 & -0.020 \\
\hline $\begin{array}{l}\text { Proportion between grassland area }\left(\mathrm{km}^{2}\right) \text { and total area }\left(\mathrm{km}^{2}\right) \\
\text { in } 500 \mathrm{~m} \text { riparian zones }(\%)\end{array}$ & -0.098 & 0.158 & 0.040 \\
\hline $\begin{array}{l}\text { Proportion between wetland area }\left(\mathrm{km}^{2}\right) \text { and total area }\left(\mathrm{km}^{2}\right) \\
\text { in } 500 \mathrm{~m} \text { riparian zones }(\%)\end{array}$ & -0.238 & 0.132 & 0.195 \\
\hline $\begin{array}{l}\text { Proportion between farmland area }\left(\mathrm{km}^{2}\right) \text { and total area }\left(\mathrm{km}^{2}\right) \\
\text { in } 500 \mathrm{~m} \text { riparian zones }(\%)\end{array}$ & 0.149 & -0.011 & -0.149 \\
\hline $\begin{array}{l}\text { Proportion between artificial surface area }\left(\mathrm{km}^{2}\right) \text { and total area }\left(\mathrm{km}^{2}\right) \\
\text { in } 500 \mathrm{~m} \text { riparian zones }(\%)\end{array}$ & -0.420 & 0.131 & 0.383 \\
\hline $\begin{array}{l}\text { Proportion between other land use area }\left(\mathrm{km}^{2}\right) \text { and total area }\left(\mathrm{km}^{2}\right) \\
\text { in } 500 \mathrm{~m} \text { riparian zones }(\%)\end{array}$ & 0.418 & 0.208 & -0.513 \\
\hline $\begin{array}{l}\text { Proportion between total area of forest, grassland and wetland }\left(\mathrm{km}^{2}\right) \\
\text { and total area }\left(\mathrm{km}^{2}\right) \text { in } 500 \mathrm{~m} \text { riparian zones }(\%)\end{array}$ & $0.762^{* *}$ & 0.051 & $-0.808^{* *}$ \\
\hline $\begin{array}{l}\text { Proportion between forest area }\left(\mathrm{km}^{2}\right) \text { and total area }\left(\mathrm{km}^{2}\right) \\
\text { in } 1000 \mathrm{~m} \text { riparian zones }(\%)\end{array}$ & 0.069 & -0.143 & -0.016 \\
\hline $\begin{array}{l}\text { Proportion between grassland area }\left(\mathrm{km}^{2}\right) \text { and total area }\left(\mathrm{km}^{2}\right) \\
\text { in } 1000 \mathrm{~m} \text { riparian zones }(\%)\end{array}$ & -0.093 & 0.148 & 0.039 \\
\hline $\begin{array}{l}\text { Proportion between wetland area }\left(\mathrm{km}^{2}\right) \text { and total area }\left(\mathrm{km}^{2}\right) \\
\text { in } 1000 \mathrm{~m} \text { riparian zones }(\%)\end{array}$ & -0.333 & 0.190 & 0.270 \\
\hline $\begin{array}{l}\text { Proportion between the farmland area }\left(\mathrm{km}^{2}\right) \text { and total area }\left(\mathrm{km}^{2}\right) \\
\text { in } 1000 \mathrm{~m} \text { riparian zones }(\%)\end{array}$ & 0.137 & -0.004 & -0.140 \\
\hline $\begin{array}{l}\text { Proportion between artificial surface area }\left(\mathrm{km}^{2}\right) \text { and total area }\left(\mathrm{km}^{2}\right) \\
\text { in } 1000 \mathrm{~m} \text { riparian zones }(\%)\end{array}$ & -0.365 & 0.093 & 0.340 \\
\hline $\begin{array}{l}\text { Proportion between other land use area }\left(\mathrm{km}^{2}\right) \text { and total area }\left(\mathrm{km}^{2}\right) \\
\text { in } 1000 \mathrm{~m} \text { riparian zones }(\%)\end{array}$ & 0.395 & 0.191 & -0.482 \\
\hline $\begin{array}{l}\text { Proportion between the total area of forest, grassland and wetland }\left(\mathrm{km}^{2}\right) \\
\text { and total area }\left(\mathrm{km}^{2}\right) \text { in } 1000 \mathrm{~m} \text { riparian zones }(\%)\end{array}$ & $0.808^{* *}$ & 0.026 & $-0.845^{* *}$ \\
\hline $\begin{array}{l}\text { Proportion between forest area }\left(\mathrm{km}^{2}\right) \text { and total area }\left(\mathrm{km}^{2}\right) \\
\text { in } 2000 \mathrm{~m} \text { riparian zones }(\%)\end{array}$ & 0.058 & -0.118 & -0.014 \\
\hline $\begin{array}{l}\text { Proportion between grassland area }\left(\mathrm{km}^{2}\right) \text { and total area }\left(\mathrm{km}^{2}\right) \\
\text { in } 2000 \mathrm{~m} \text { riparian zones }(\%)\end{array}$ & -0.075 & 0.137 & 0.024 \\
\hline $\begin{array}{l}\text { Proportion between wetland area }\left(\mathrm{km}^{2}\right) \text { and total area }\left(\mathrm{km}^{2}\right) \\
\text { in } 2000 \mathrm{~m} \text { riparian zones }(\%)\end{array}$ & -0.404 & 0.241 & 0.324 \\
\hline $\begin{array}{l}\text { Proportion between farmland area }\left(\mathrm{km}^{2}\right) \text { and total area }\left(\mathrm{km}^{2}\right) \\
\text { in } 2000 \mathrm{~m} \text { riparian zones }(\%)\end{array}$ & 0.116 & -0.004 & -0.119 \\
\hline $\begin{array}{l}\text { Proportion between artificial surface area }\left(\mathrm{km}^{2}\right) \text { and total area }\left(\mathrm{km}^{2}\right) \\
\text { in } 2000 \mathrm{~m} \text { riparian zones }(\%)\end{array}$ & -0.322 & 0.066 & 0.307 \\
\hline $\begin{array}{l}\text { Proportion between other land use area }\left(\mathrm{km}^{2}\right) \text { and total area }\left(\mathrm{km}^{2}\right) \\
\text { in } 2000 \mathrm{~m} \text { riparian zones }(\%)\end{array}$ & 0.397 & 0.166 & -0.475 \\
\hline
\end{tabular}




\section{Continued table}

\begin{tabular}{llll} 
Water quality & \\
\cline { 2 - 4 } Influencing factors & Grades I, II and III (\%) & Grades IV and V (\%) & Worse than Grade V (\%) \\
\hline
\end{tabular}

\begin{tabular}{|c|c|c|c|}
\hline $\begin{array}{l}\text { Proportion between total area of forest, grassland and wetland }\left(\mathrm{km}^{2}\right) \\
\text { and total area }\left(\mathrm{km}^{2}\right) \text { in } 2000 \mathrm{~m} \text { riparian zones }(\%)\end{array}$ & $0.788^{* *}$ & 0.039 & $-0.829^{* *}$ \\
\hline Gross agricultural output density (10 000 yuan (RMB) $/ \mathrm{km}^{2}$ ) & $-0.562^{*}$ & -0.229 & $0.670^{* *}$ \\
\hline Gross crop output density (10 000 yuan (RMB) $/ \mathrm{km}^{2}$ ) & $-0.616^{*}$ & -0.225 & $0.724^{* *}$ \\
\hline Gross stockbreeding output density (10000 yuan $\left.(\mathrm{RMB}) / \mathrm{km}^{2}\right)$ & -0.322 & -0.270 & 0.438 \\
\hline Rural per capita net income (10 000 yuan (RMB)/person) & -0.215 & -0.245 & 0.317 \\
\hline Agricultural population density $\left(10\right.$ persons $\left./ \mathrm{km}^{2}\right)$ & $-0.630^{*}$ & -0.319 & $0.775^{* *}$ \\
\hline Pesticide application intensity $\left(1000 \mathrm{~kg} / \mathrm{km}^{2}\right)$ & $-0.623^{*}$ & -0.148 & $0.702^{* *}$ \\
\hline Fertilizer application intensity $\left(1000 \mathrm{~kg} / \mathrm{km}^{2}\right)$ & $-0.562^{*}$ & -0.180 & $0.651^{* *}$ \\
\hline Agriculture GDP density (10000 yuan (RMB) $/ \mathrm{km}^{2}$ ) & -0.507 & -0.360 & $0.664^{* *}$ \\
\hline Industry GDP density (10 000 yuan (RMB)/km²) & -0.422 & -0.439 & $0.607^{*}$ \\
\hline Services GDP density (10 000 yuan $\left.(\mathrm{RMB}) / \mathrm{km}^{2}\right)$ & -0.423 & -0.496 & $0.630^{*}$ \\
\hline Industrial wastewater emissions intensity $\left(1000 \mathrm{~kg} / \mathrm{km}^{2}\right)$ & -0.495 & -0.251 & $0.609^{*}$ \\
\hline Industrial wastewater COD emissions intensity $\left(1000 \mathrm{~kg} / \mathrm{km}^{2}\right)$ & -0.403 & -0.151 & 0.475 \\
\hline Industrial wastewater amino nitrogen emissions intensity $\left(1000 \mathrm{~kg} / \mathrm{km}^{2}\right)$ & $-0.728^{* *}$ & -0.049 & $0.771^{* *}$ \\
\hline Domestic wastewater emissions intensity $\left(1000 \mathrm{~kg} / \mathrm{km}^{2}\right)$ & $-0.524^{*}$ & -0.288 & $0.654^{* *}$ \\
\hline Domestic wastewater COD emissions intensity $\left(1000 \mathrm{~kg} / \mathrm{km}^{2}\right)$ & $-0.651^{* *}$ & -0.366 & $0.815^{* *}$ \\
\hline Domestic wastewater amino nitrogen emissions intensity $\left(1000 \mathrm{~kg} / \mathrm{km}^{2}\right)$ & $-0.644^{* *}$ & -0.362 & $0.806^{* *}$ \\
\hline
\end{tabular}

Notes: **: significant at 0.01 level (double side); *: significant at 0.05 level (double side). GDP: Gross Domestic Product; COD: Chemical Oxygen Demand 